\title{
Properties of Ternary Cementitious Concrete Matrix Containing Rice Husk Ash and Coconut Husk Ash
}

\author{
Engr. Ikri Samuel Obokparo, Prof. C. N. Arum \\ Benson Idahosa University
}

\begin{abstract}
The environmental pollution resulting from the production process of cement has contributed to the climate change being experienced worldwide. The need to reduce the rate of depletion of the ozone layer and also to produce durable and sustainable concrete has led to this study. Eighty four (84) concrete cubes of $150 \mathrm{~mm} \times 150 \mathrm{~mm} \times 150 \mathrm{~mm}$ were produced with OPC /RHA / CHA blended concrete at percentage OPC replacement with pozzolans of $5 \%, 10 \%$, $15 \%$ and $20 \%$. Twenty one (21) concrete cubes were cast as control. Cubes from the concrete mixes were cured for 7,14 , $28,35,42,49$ and 56 days and were crushed to determine their compressive strengths. Experimental work was carried out on OPC/RHA /CHA concrete to determine their essential properties in fresh and hardened state, they are all within the limits specified by relevant standards. It was observed that at $10 \%$ replacement the maximum compressive strength of $32.9 \mathrm{~N} / \mathrm{mm}^{2}$ was obtained for the ternary blended concrete of OPC / RHA /CHA at 56 days, representing $16.1 \%$ increase in strength over the $100 \%$ OPC concrete, indicating the optimal value of compressive strength attained. This indicate that RHA and CHA combination is an excellent pozzolans that can be utilize for both binary and ternary blended concrete production.
\end{abstract}

Keywords: Pozzolans, Ternary, Ozone layer, Pollution, Rice husk ash, Coconut husk ash.

\section{INTRODUCTION}

Concrete is a composite construction material composed primarily of aggregate, cement and water. Concrete has been considered the first widely used construction material throughout the world. Over the years it has been used in vast quantity for the construction of buildings, bridges, roads, dams and many other civil infrastructures. According to Glavind and Munch-Petersen (2002), its worldwide annual consumption in 2002 was about 5 billion $\mathrm{m}^{3}$. Moreover, it has been predicted that its demand would double every decade (Mehta, 2001). Hence its performance and effects on the environment are of great importance.

Compared to other constituents, cement performs a vital role for the production of concrete. However, the production process of cement causes some negative effect to the natural environment, in addition to the high cost of cement due to continuous increase in the demand. The process of making cement is among the third largest $\mathrm{CO}_{2}$ producers in the world. According to Malhotra, (2002), during this process, for every ton of cement produced, more than half of all $\mathrm{CO}_{2}$ emissions are released into the air. These greenhouse gases $\left(\mathrm{CO}_{2}\right.$ and $\left.\mathrm{SO}_{2}\right)$ contribute to the depletion of the ozone layer which leads to global warming. This dramatic increase in $\mathrm{CO}_{2}$ emissions from cement production has been stated by Mugaet al., (2005). Undeniably, cement production depends on many other factors, more often than not, the production of cement is an extremely energy intensive production process because the energy and the consumption of other natural resources per ton are estimated to be approximately 4GJ and 1.6 ton (Mugaet al.,2005). Given the relationships between life cycle characteristics and $\mathrm{CO}_{2}$ use, the emission of $\mathrm{CO}_{2}$ can be assessed for environmentally friendly concrete production (Park et al., 2012). To combat the aforementioned problem, cement can be partially replaced by supplementary cementitious materials, such as industrial by-product (fly ash, silica fume and slag) and agricultural wastes (rice husk ash, coconut husk ash, palm oil fuel ash and ash from timber). Most of these supplementary cementing materials are by-products; thus, their inclusion not only serves as an invaluable means to preserve environmental resources but also enhances concrete construction properties including its sustainability (Aitcin, 1998; Mehta and Monteiro, 2006).

Supplementary cementitious material- is a material that when used in conjunction with Portland cement contributes to the properties of the concrete through hydraulic or pozzolanic activity. Supplementary cementitious materials include the many products that are mixed with either water or some other liquids or both to form a cementing paste that may be formed or moulded whole plastic but will set into a rigid shape. When sand is added to the paste, mortar is formed. A combination of coarse and fine aggregates added to the paste forms concrete (Lea, 1970). The use of supplementary cementitious materials, date back to the ancient Greeks, who incorporate volcanic ash with hydraulic lime to create a cementitious mortar. The Greek passed this knowledge onto the Romans, who constructed such engineering marvels as the Roman aqueducts and the coliseum, which still stand today. The practice of using supplementary cementitious materials in concrete has been growing in North America since the 1970s (Bentur et al., 1994). The optimum combination of materials will vary for different performance requirements and the type of supplementary cementitious materials. The ready mixed concrete producer, with knowledge of the locally available materials, can establish the mixture proportions for the required performance. Most often, a supplementary cementitious material will be used to replace a portion of the cement content for economical or propertyenhancement reasons (Lea,1970). According to (Bakar et al., 2010 ), supplementary cementitious materials prove to be effective to meet most of the requirements of durable 
concrete and that blended cements are now used in many parts of the world. Supplementary cementitious materials added directly to concrete are governed by ASTM C618, 2005 (Fly Ash and Pozzolans), C989, 1993 (slag), or C1240, 1993 (Silica Fume), while blended cements are governed by ASTM C595, 1994 or C1157, 1994. American Society for Testing and Materials ASTM C150, (2005) defined Blended Cement (BC) as cement mixtures containing Portland cement and one or more supplementary cementitious materials (SCMs), with the potential benefits of reducing the overall concrete cost, improving concrete workability, durability and long term strength. Horst (2001) elucidated further that $\mathrm{BC}$ as a technical term, often refers to cement products that are factory blended by cement companies while on the site mixing with the OPC is referred to as 'partial replacement'. Pozzolans are utilized as SCMs in cement blending or partial replacements of the ordinary Portland cement in concrete mixes.

Although the use of BBC can be dated back many years ago, the use of multi-blended cement with more than two or three supplementary cementitious materials is still new. One reason is the complex nature of the materials that are utilized in the concrete; hence, adequate information is necessary to create a sustainable product. Despite this disadvantage, the advantages of using MBC outweigh those of BBC. A large number of studies have been conducted to analyze the MBC system, and have come to the conclusion that, due to their effects on strength and durability, the application is more beneficial in structures in hostile environments (Khan et al., 2000). Using more than one waste pozzolan has also proven to be advantageous technically, economically and environmentally. However, due to their different properties, these waste minerals might show various reactions when they are mixed with water (Toutanjiet al., 2004).

The use of Pozzolans in concrete can either be to partially replace cements or be added to concrete mix to perform special purposes. Pozzolans are often cheaper than Portland cement which they replace, but their major advantage lies in the slow hydration and therefore low rate of heat development (Bamforth, 1980).A partial replacement of Portland cement by pozzolan is most used in mass concrete construction work. Also, partial replacement of Portland cement by pozzolan in concrete gives good resistance to sulphate attack and some other destructive agents. This is a result of pozzolanic reaction, leaving less lime to be leached out. It also reduces the permeability of concrete (Kovacs, 1975).

Rice Husk $(\mathrm{RH})$ is a waste product generated from the accumulation of the outer covering of rice during the milling process, which in most cases are disposed of or burnt. When the rice husk is burnt at a high temperature, it is converted into ash, hence the name, Rice Husk Ash (RHA). Rice Husk Ash may be productively used as a partial substitute of cement in concrete. Houston (1972) classified the ash into; High carbon char; Low-carbon (grey) ash; carbon free (pink or white) ash. Most rice husks are straw or gold in color, though some maybe white russet, red, Brown, shade of purple or sooty black, depending on species. The length of rice husk is about 5 to $10 \mathrm{~mm}$ and the width varies from 2.5 to $5 \mathrm{~mm}$.

The pozzolanic effect of RHA is attributed to the ability of silica to combine with silicate hydrates. In comparison to the hydration process of cement, the reaction of RHA in the presence of moisture is very slow. This is due to the presence of traces of sulphate and the high percentage of silica. The coating of the seeds or grains (husk) of rice plant can absorb significant amounts of silica (approximately 85\%) from the soil during its growth period (Smith and Kamwanja, 1986; siddique, 2008). Rice husk are by-products that are responsible for $20 \%$ of the RHA weight after the husk have been burned (Anwar et al; 2001). With it high specific surface area and noncrystalline features can result in highly pozzolanic reactions (Tashima et al., 2004). Hence, this is considered a better alternative for Portland cement in fillers for high performance concrete (Smith and Kamwanja, 1986; Zhang et al., 1996; Hasparyket al., 2000; Sakr, 2006; Sataet al., 2007).

The high silica content in the form of non-crystalline or amorphous silica of Rice Husk Ash is dependent on the burning temperatures; $95 \%$ silica could be produced after heating at $700^{\circ} \mathrm{C}$ for 6 hours. According to ( Karim et al., 2012), when Rice Husk is burnt into ash it fulfills the physical characteristics and the chemical composition of mineral admixture, the pozzolanic activity of Rice Husk Ash is influenced by (i) silica content (ii) silica crystallization phase and (iii) size and surface area of the ash particles. Habeeb and Fayyadh (2009), investigated the influence of RHA average particle size on the properties of concrete and found that at early ages the strength was comparable, while at the age of 28 days, finer RHA exhibited higher strength than the sample with coarser Rice Husk Ash.

Coconut Husk is an agricultural waste and is available in very large quantities throughout the tropical countries of the world. Some tropical people called coconut as "the tree of life" because the meat and milk of the nut give them food and drink. The trunk of the tree produces beautiful and durable wood for their homes. Floor mats and clothing can also be made from the coconut husk.Bamgboye and Jekayinfa, (2006) regretted that $90 \%$ of coconut (empty fruit bunches, husk, trunks, shells) was discarded as waste and either burned in the open air or left to settle in waste ponds. This way, the coconut processing industrial waste according to them, contributed significantly to $\mathrm{CO}_{2}$ and methane emissions. Based on economic as well as environmental related issues, efforts should be directed worldwide towards coconut management issues i.e. utilization, storage and disposal. The ash obtained from burning of coconut husk at a high temperature is referred to as Coconut Husk Ash (CHA).An investigation on the physical properties of Coconut Husk Ash by Raghu and Chaitanya (2007) revealed that the colour of the ash obtained by burning coconut husk in the Ferro cement incinerator was found to possess a darkish grey colour. The ash produced was only $2.8 \%$ by weight of the unburnt coconut husk, meaning that burning $25 \mathrm{~kg}$ of coconut husk which is the capacity of the small Ferro cement incinerator 
produced only $0.7 \mathrm{~kg}$ of ash in one hour. The burning temperature at $750^{\circ} \mathrm{C}$.

This research is therefore concerned about the need to widen the information base on the pozzolanic properties of Ekpoma rice husk ash, coconut husk ash and their combination for the production of ternary concrete. These pozzolans can serve as cheap materials to partially replace Portland cement. Finally, these materials are readily available and partial replacement of Portland cement with these materials will produce a more economical concrete.

\section{MATERIALS AND METHODS}

\section{Materials}

The main cementitious material was the Ordinary Portland Cement while the fine aggregate used were natural river sand samples passing through $4.25 \mathrm{~mm}$ sieve. Coarse aggregate used were obtained from a nearby Quarry. The maximum size of coarse aggregate used was $20 \mathrm{~mm}$. potable water free from salts was used for casting in all mixes during the experiment as well as for curing purposes. Coconut husk was obtained from a dump site at Oyo abayo farm settlement beside Federal University of Technology, Akure, Ondo state and the rice husk was obtained from a rice mill in Ekpoma, Edo state, Nigeria.

\section{Methods \\ Materials Preparation, Particle Sizes Distribution Test and Specific Gravity Test}

The specific gravity was calculated from;

Specific gravity, Gs $=\frac{M_{2}-M_{1}}{\left(M_{4}-M_{1}\right)-\left(M_{3}-M_{2}\right)}$

where,

$\mathrm{M}_{1}$ is the mass of glass jar + lid ( $\left.\mathrm{g}\right)$

$\mathrm{M}_{2}$ is the mass of glass jar + lid + Sample ( $\mathrm{g}$ )

$\mathrm{M}_{3}$ is the mass of glass jar + lid + water $(\mathrm{g})$
The coconut husk and the rice husk were sun dried and burned in the muffle furnace at the foundry of the Metallurgical and Materials Engineering Department, Federal University of Technology, Akure, for 6 hours at $700^{\circ} \mathrm{C}$ separately. After burning for 6 hours, the ash was allowed to cool for 72 hours and the fine particles were further sieved through a sieve of $45 \mu \mathrm{m}$ aperture size. The particles passing the sieve were thus used as the pozzolan with OPC at different percentage replacement. The type of particle size distribution employed in this study was the dry sieving which is an alternative method to wet sieving which is done for samples that contain clay or other materials likely to cause agglomeration of particles. The specific gravity test was carried out on river sand, granite, Ekpoma rice husk ash and coconut husk ash based on the guidelines proffered by BS 882 (1992). The aggregates were first sieved through a $2 \mathrm{~mm}$ aperture sieve before proceeding through the test procedure. The glass jar was washed and cleaned and allowed to dry to remove all the water in it. It was weighed with the lid and recorded as $\mathbf{M}_{1}$. The jar + lid + the sample was weighed and recorded as $\mathrm{M}_{2}$. The sample was removed from the glass jar, the jar + lid + water (filled to the brim) was weighed and recorded as $\mathrm{M}_{4}$. The sample was put into the jar and filled with water up to half of the jar and left for 30 minutes. The jar was filled with water up to three - quarter of the jar and left for 24 hours. After 24 hours, the glass jar was filled to the brim without disturbing the sample and left for 30 minutes and recorded as $\mathrm{M}_{3}$.

RESULTS

Table 1: Proportion Of Cement, Ashes and Aggregates Used For Concrete Mix

\begin{tabular}{|c|c|c|c|c|c|c|c|}
\hline $\begin{array}{c}\text { Replacement } \\
(\%) \\
\end{array}$ & Number & $\begin{array}{l}\text { Cement } \\
\text { Content } \\
(\mathrm{kg})\end{array}$ & $\begin{array}{c}\text { Rice Husk } \\
\text { Ash } \\
\text { Content } \\
(\mathrm{kg})\end{array}$ & $\begin{array}{c}\text { Coconut } \\
\text { Husk Ash } \\
\text { Content } \\
(\mathrm{kg})\end{array}$ & $\begin{array}{c}\text { RH and } \\
\text { CH Ashes } \\
\text { Content } \\
(\mathrm{kg})\end{array}$ & $\begin{array}{l}\text { Sand } \\
(\mathrm{kg})\end{array}$ & Granite \\
\hline 0 & 21 & 21.86 & & & & 43.72 & 87.44 \\
\hline 5 & 63 & 62.3 & 2.06 & 2.06 & 2.06 & 124.6 & 249.2 \\
\hline 10 & 63 & 59.02 & 4.12 & 4.12 & 4.12 & 118.04 & 236.08 \\
\hline 15 & 63 & 55.74 & 6.17 & 6.17 & 6.17 & 111.48 & 222.96 \\
\hline 20 & 63 & 52.46 & 8.23 & 8.23 & 8.23 & 104.92 & 209.84 \\
\hline TOTAL & 273 & 251.38 & 20.58 & 20.58 & 20.58 & 502.76 & 1005.52 \\
\hline
\end{tabular}

Table 2: $\quad$ Natural Moisture Content Test Result on River Sand

\begin{tabular}{|c|c|c|c|c|}
\hline $\begin{array}{l}\text { Moisture content } \\
\text { Can Number }\end{array}$ & $\begin{array}{c}\text { Mass of empty can } \\
\mathrm{M}_{1}(\mathrm{~g})\end{array}$ & $\begin{array}{c}\text { Mass of can }+ \text { Wet } \\
\text { sample, } \mathrm{M}_{2}(\mathrm{~g})\end{array}$ & $\begin{array}{c}\text { Mass of can }+ \\
\text { Dry sample, } M_{3}(g) \\
\end{array}$ & $\begin{array}{c}\text { Moisture } \\
\text { Content (\%) }\end{array}$ \\
\hline CAN 1 & 46.9 & 98.8 & 95.5 & 6.79 \\
\hline CAN 2 & 43.4 & 101.8 & 97.7 & 7.55 \\
\hline CAN 3 & 43.2 & 102.8 & 99.1 & 6.62 \\
\hline
\end{tabular}


The relationship between compressive strength of concrete and SCM replacement levels at different days of curing are shown in the figures below.

7 DAYS

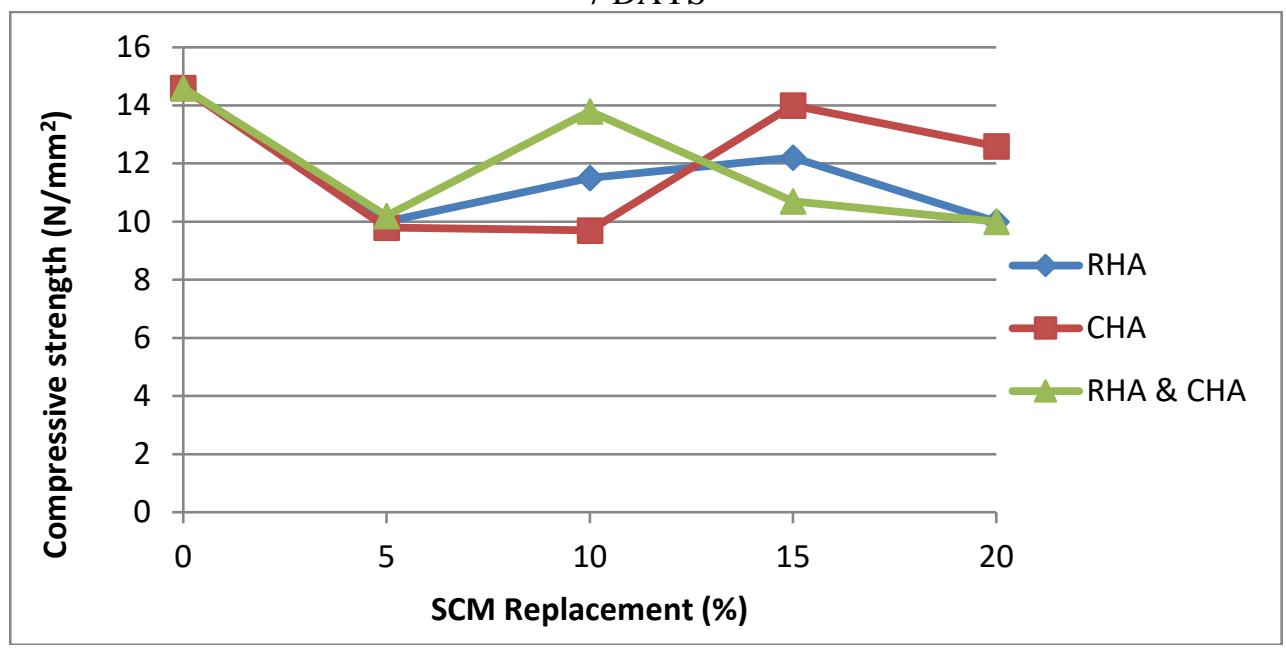

Figure 1: Relationship between Compressive Strength of Concrete and SCM replacement level at 7 days

14 DAYS

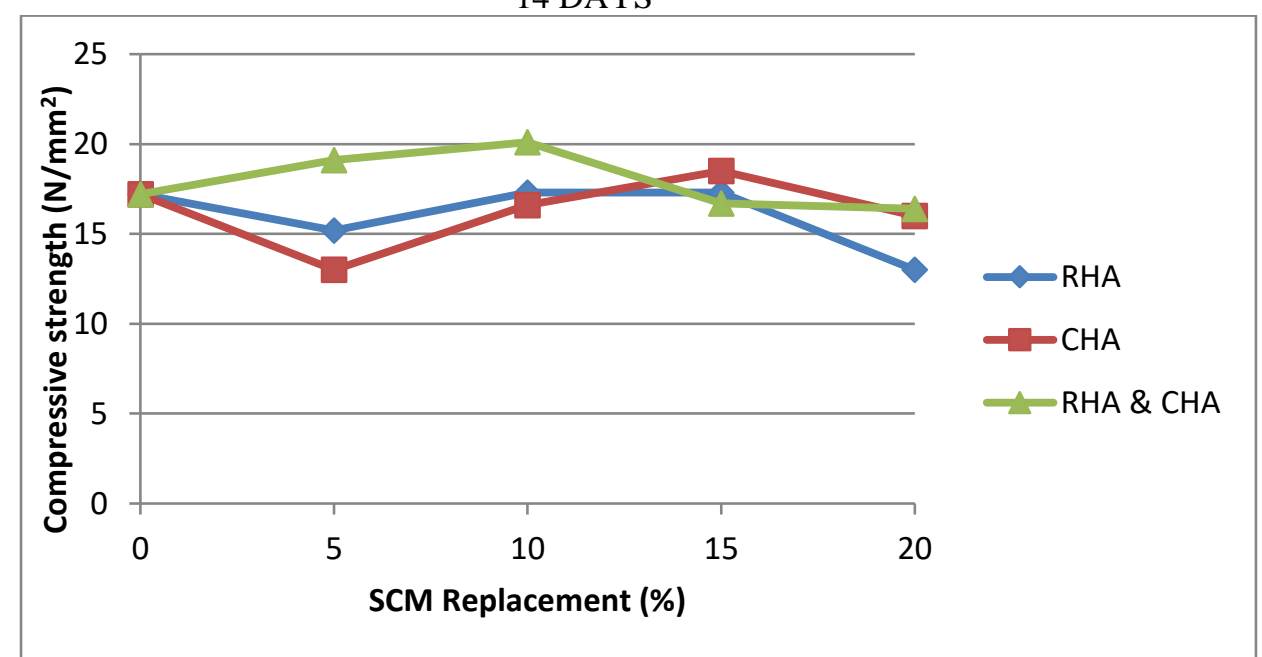

Figure 2: Relationship between Compressive Strength of Concrete and SCM replacement level at 14 days

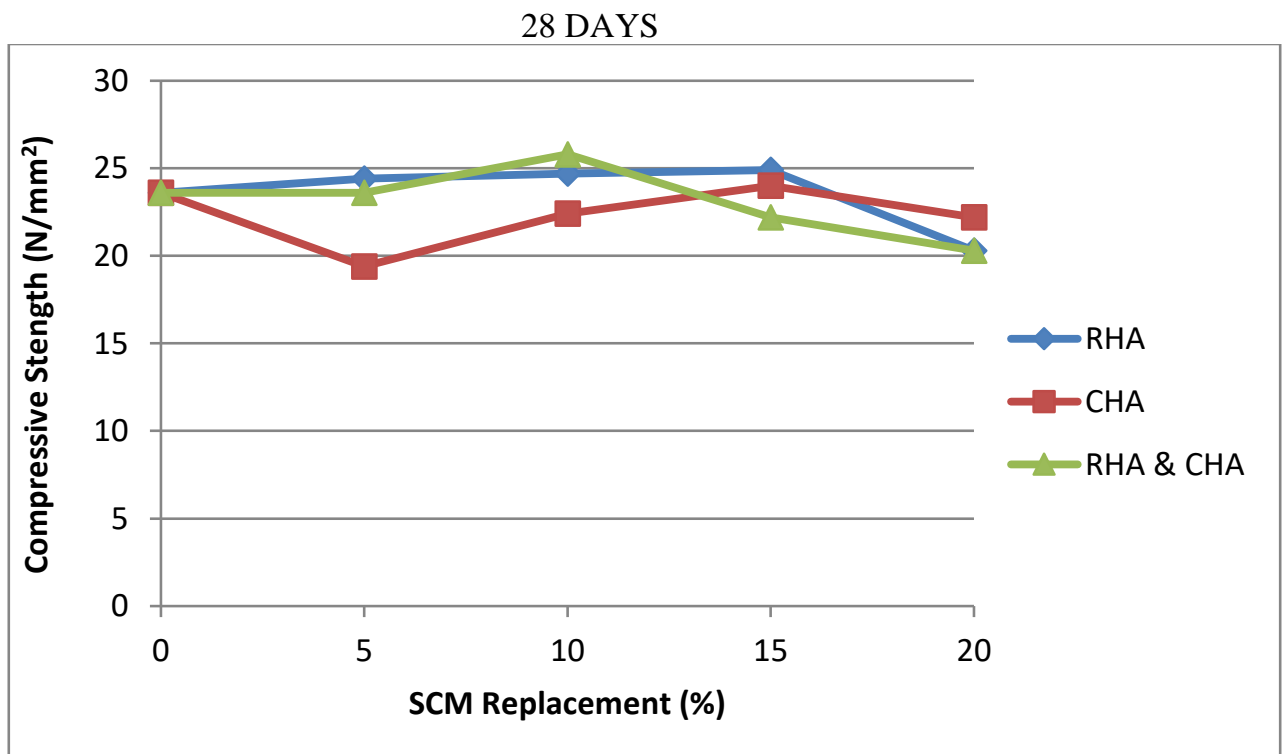

Figure 3: Relationship between Compressive Strength of Concrete and SCM replacement level at 28 days 
35 DAYS

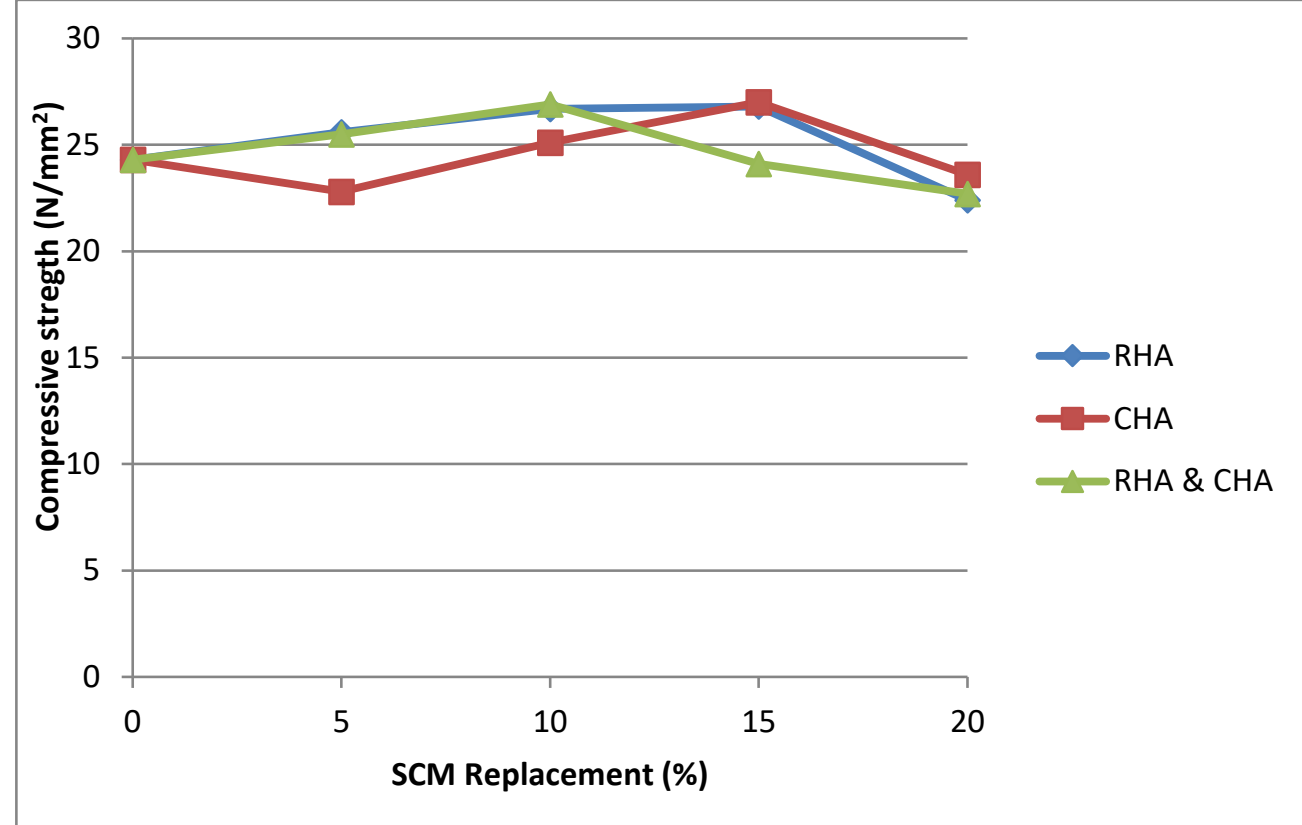

Figure 4: Relationship between Compressive Strength of Concrete and SCM replacement level at 35 days

42 DAYS

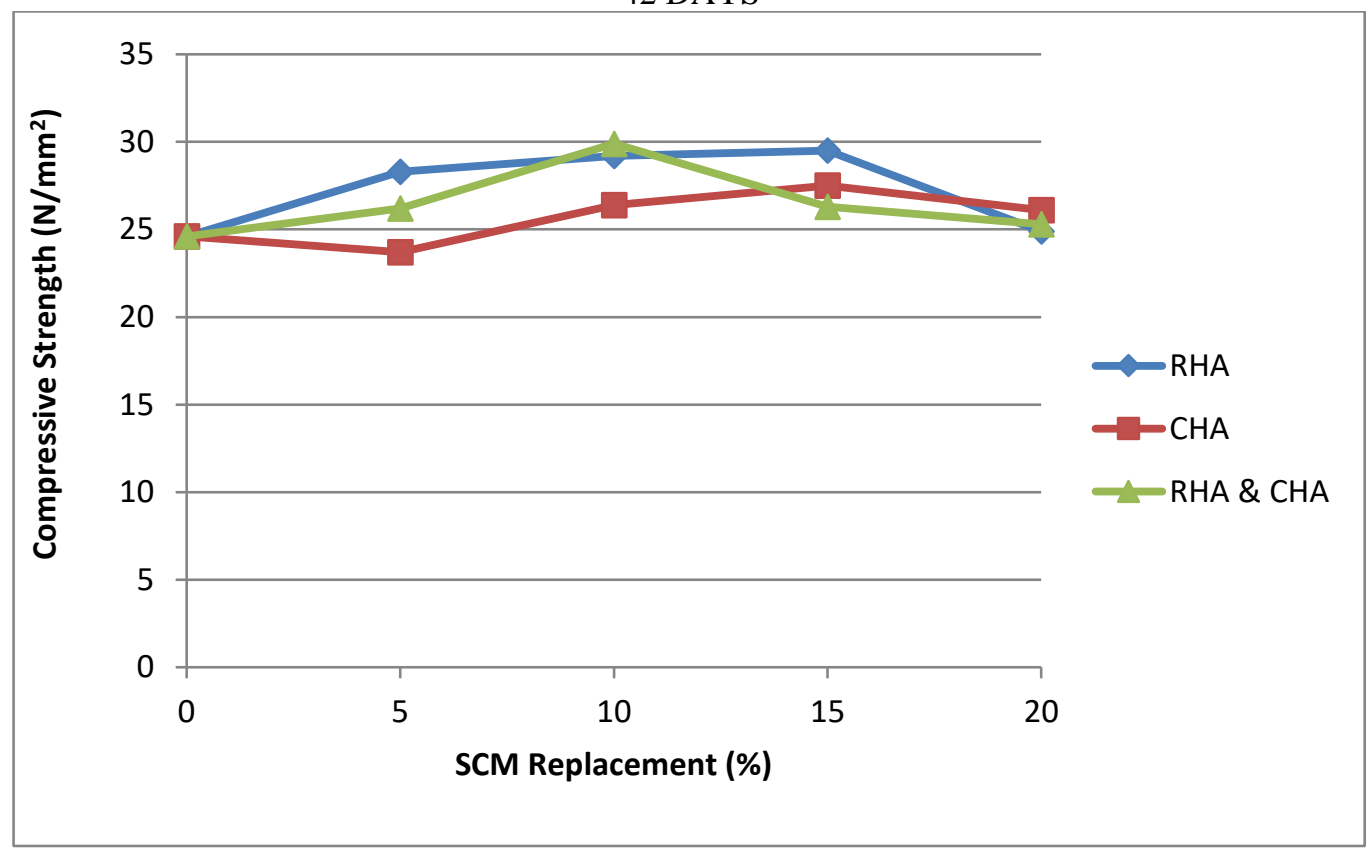

Figure 5: Relationship between Compressive Strength of Concrete and SCM replacement level at 42 days 
49 DAYS

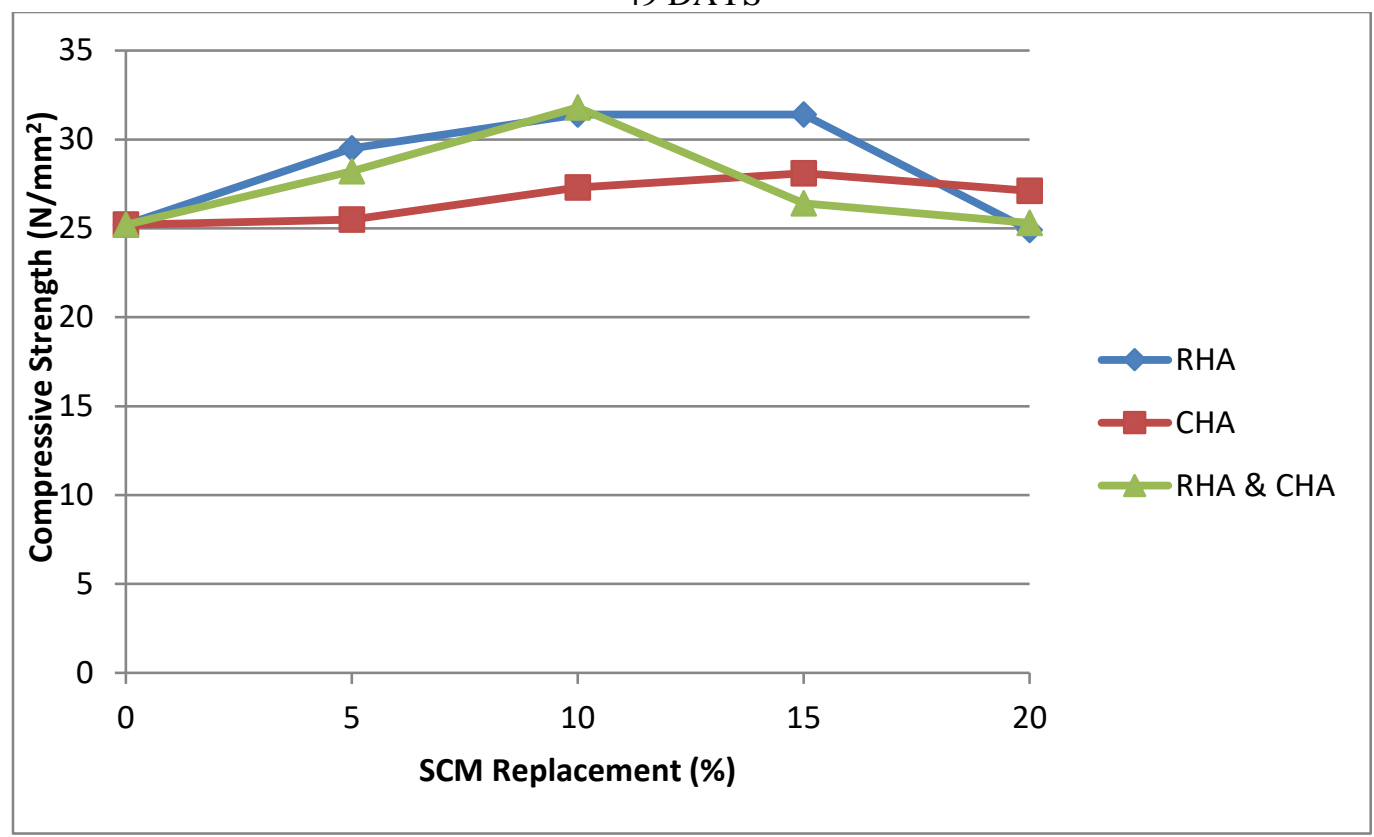

Figure 6: Relationship between Compressive Strength of Concrete and SCM replacement level at 49 days

56 DAYS

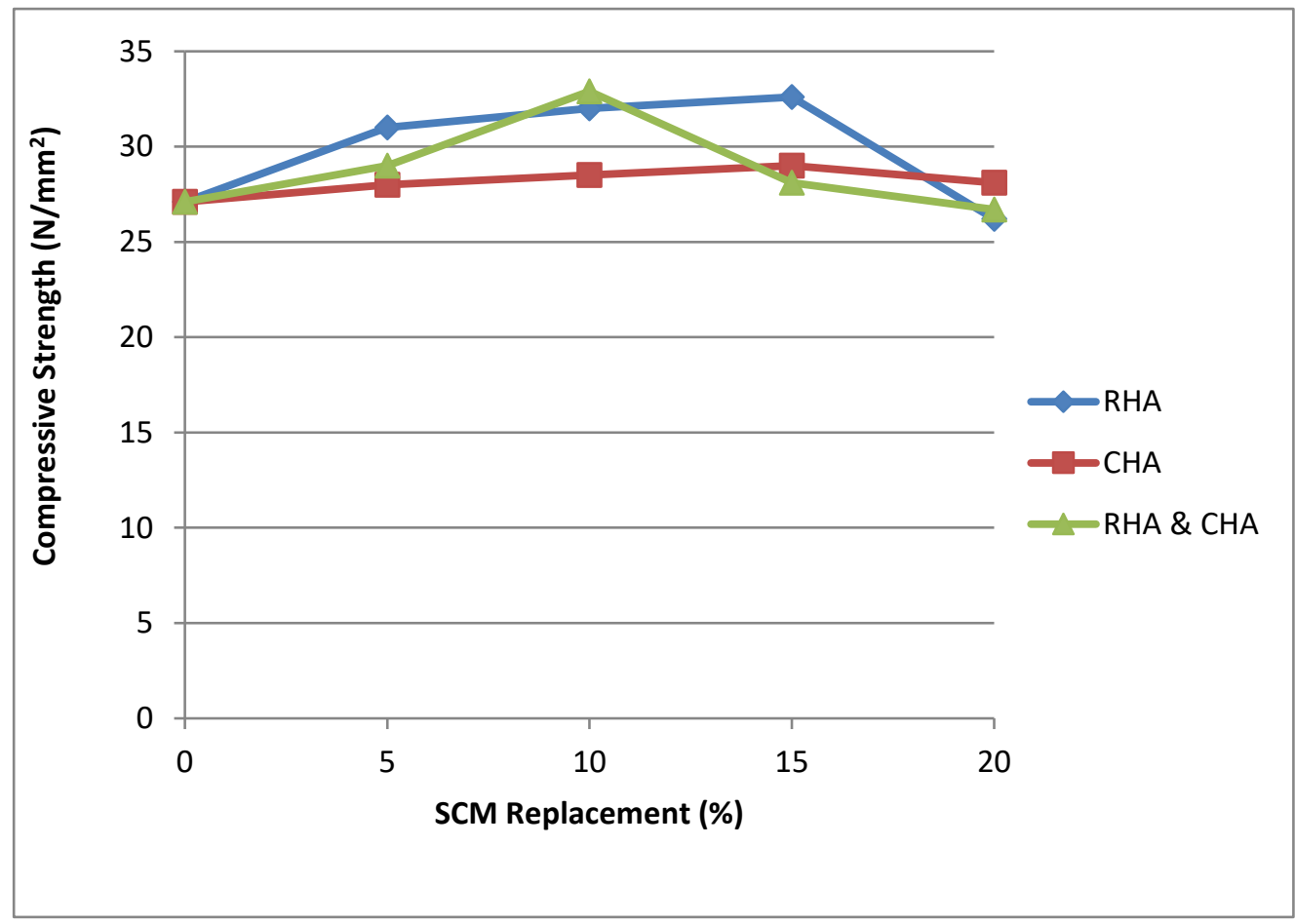

Figure 7: Relationship between Compressive Strength of Concrete and SCM replacement level at 56 days

\section{CONCLUSION}

From the experimental results obtained in this investigation, rice husk ash and coconut husk ash for making cement, using Elephant brand of ordinary Portland cement in combination, the following conclusions are drawn:

(a) The X-Ray Fluoresce (XRF) of rice husk ash (RHA) and coconut husk ash (CHA) revealed silicon oxide $\left(\mathrm{SiO}_{2}\right)$ as the highest percentage of all the compound and element present. (b) The evaluation of the chemical characteristics of Ekpoma rice husk ash and coconut husk ash indicated that the materials met the ASTM C618 (2005) Specification for pozzolan to be used as supplementary cementitious materials in ordinary Portland cement concrete. It is thus conclusive that these materials are good supplementary cementitious materials for use in concrete production.

(c) The setting time of Elephant brand of ordinary Portland cement partially replaced by Ekpoma rice husk ash and 
coconut husk ash increased with increase in percentage replacement

(d) The fineness of cement was improved when the supplementary cementitious materials were added.

(e) Introduction of the SCMs made the various concrete tested to be less porous than the control mix, from the air entrainment test.

(f) In the workability of concrete, there was a decrease with each percentage replacement in the compacting factor of unhardened concrete and the slump decreased till the $15 \%$ replacement then started increasing for RHA and RHA \& CHA. Also, the slump for CHA decreased at 5\% then started increasing gradually, making the concrete adequately workable.

(g) All the concrete with the various percentage replacements tested has greater compressive strength values at 56 days as compared with that at $0 \%$ replacement, except for $20 \%$ RHA and $20 \%$ RHA \& CHA.

(h) The compressive strength values for 15\% RHA, $15 \% \mathrm{CHA}$ and 10\%RHA \& CHA at 28 and 56 days of curing are higher than the compressive strength of $100 \%$ $\mathrm{OPC}$ at the same days.

(i) The utilization of supplementary cementitious materials in either cement or concrete can compensate for environmental, technical and economic issues caused by cement production. Most of these supplementary cementitious materials are by-products, and their inclusion serves as an invaluable means to protect environmental resources and the production of durable concrete.

(j) The use of supplementary cementitious material reduces porosity of concrete as can be seen from the air entrainment test, thereby leading to the production of durable concrete.

(k) The ternary blended concrete of OPC/RHA/CHA at $10 \%$ replacement gave the maximum compressive strength and that makes it more preferable in terms of strength.

\section{REFERENCES}

[1] Aitcin, P.C., (1998). High Performance Concrete. Taylor and Francis, USA. P 624

[2] Anwar, M., Miyagawa, T., Gaweesh, M, (2001). Using Rice Husk Ash as a Cement Replacement Material in Concrete. Proceedings of the $1^{\text {st }}$ International Ecological Building Structure Conference, July 5-9, 2001. San Rafael, CA, USA, pp. 671-684.

[3] ASTM C125 (2011). Standard Terminology Relating to Concrete and Concrete Aggregate, America Society for Testing and Materials, West Conshohocken.

[4] ASTM C219, (2007). Standard Terminology Relating to Hydraulic Cement, America Society for Testing and Materials, West Conshohocken.

[5] ASTM C150 (2005). Standard Specification for Portland Cement, America Society for Testing and Materials, West Conshohocken.

[6] ASTM C595 (1994). Specification for Blended Hydraulic Cement, America Society for Testing and Materials, West Conshohocken

[7] ASTM C618 (2005). Standard Specification for Coal Fly Ash and Raw or CalcinedNatural Pozzolan for Use in Concrete, America Society for Testing and Materials, West Conshohocken.

[8] ASTM C989 (1993). Specification for Ground Granulated Blast - Furnace Slag for Use in ConcreteandMortar, America Society for Testing and Materials, West Conshohocken.
[9] ASTM C1157 (1994). Performance Specification for Blended Hydraulic Cement, America Society for Testing and Materials, West Conshohocken.

[10] ASTM C1240 (1993). Specification for Silica Fume for Use in Hydraulic-Cement Concrete and Mortar, America Society for Testing and Materials, West Conshohocken.

[11] Bakar, B. H. A., Putrajaya, R. C., Abdulaziz H, (2010). Malaysian Sawdust ash- Improving theDurability and Corrosion Resistance of Concrete: Pre-review. Concrete Research Letters, 1 (1), 6-13.

[12] Bamforth, P. B., (1980). Institute Measurement of the Effect of Partial Portland Cement Replacement Using Either Fly Ash or Ground Granulated Blast Furnace Slag on the Performance of Mass Concrete, part 2,pp.777-800.

[13] Bamgboye, A.I, and Jekayinfa, S.O, (2006). Energy Consumption Pattern in Coconut Processing Operations. Agricultural Engineering International. The CIGR journal Manuscript EE 05 013. VOL. VIII.

[14] Bentur, A., Kovler, K., Goldman, A, (1994). Gypsum of improved performance using Blends with Portland Cement and Silica Fume. Nova Science Publishers, New York, USA, pp. 109-116.

[15] BS 12 (1978). Specification for Portland cement, British Standards Institution. BSI 389, Chiswick high road, London.

[16] BS 812-109 (1990). Methods for Determination of Moisture Content. British Standard Institution. BSI 389. Chiswick High Road, London.

[17] BS 882 (1992). Specification for Aggregates from Natura Sources for Concrete. British Standard Institution. BSI 389 Chiswick High Road, London.

[18] BS 1881-3 (1970). Making and Curing Test Cubes. British Standard Institution. BSI 389.Chiswick high road, London.

[19] BS 1881-102 (1983). Methods for Determination of Slump. British Standard Institution. BSI 389. Chiswick High Road, London.

[20] BS 1881 - 106 (1993). Methods for Determination of Air Entrainment. British Standard Institution.BSI 389. Chiswick High Road, London.

[21] BS 1881-108 (1983). Methods for Making Concrete Test Cubes. British Standard Institution. BSI 389. Chiswick High Road, London.

[22] BS 1881-116 (1983). Methods for Determination of Compressive Strength of Concrete Cubes. British Standard Institution. BSI389. Chiswick High Road, London.

[23] BS 1881-125 (1983). Mixing and Sampling Fresh Concrete in the Laboratory. British Standard Institution. BSI 389. Chiswick High Road, London

[24] BS 4550-3 (1978). Methods for Testing Cement. Physical Test. British Standard Institution. BSI 389. Chiswick High Road, London.

[25] European Standard EN 197- 1 (2007). Composition, Specification and Conformity Criteria for Common Cements, CEN, Brussels.

[26] Habeeb,G.A. and Fayyadh, M.M.,(2009). Rice Husk Ash Concrete: the Effect of RHA Average Particle Size on Mechanical Properties and Drying Shrinkage. Australian Journal of Basic and Applied Sciences, 3(3): 1616-1622.

[27] Hasparyk, N.P., Monteiro, P.J.M., Carasek, H, (2000). Effect of Silica Fume and Rice Husk Ash on Alkali- Silica Reaction. Mater. J., 97(4): pp. 486-492.

[28] Horst, S. (2001). Some Basics About Substituting Pozzolan for Portland Cement in Concrete. Proceedings from the Council of University States of America Green Building Summit. Arizona.

[29] Houston, D.F, (1972). Rice: Chemistry and Technology. American Association of cereal

[30] Karim M.R., Zain M.F.M., Jamil M., Lai F.C, Islam M.N., (2012). Strength of Mortar and Concrete as Influenced by Rice Husk Ash: A Review. World Applied Sciences Journal 19(10): 1501-1513.

[31] Khan, M.I., Lyndsdale C.J., Waldron, P, (2000). Porosity and Strength of PFA/SF/OPC/ Ternary Blended Paste. Cement Concrete Res., 30: 1225-1229. 
[32] Kovacs, R., (1975), Effect of Hydration Producings on the Properties of Fly Ash Cements Concrete Research, Pp. 73 82.

[33] Lea, F.M, (1970). The Chemistry of Cement and Concrete. Third Edition. Armold Edward Publishers, London, pp. 126.

[34] Lenahan M., (2010). Cupola Furnace Slag in As

[35] Malhotra V.M., (2002). Introduction: Sustainable Development and Concrete Technology, ACI Concrete International 24 (7):Pp. 22.

[36] Malhotra, V. M., Jiang L.H., (2000). Reduction in Water Demand of Non Air - EntrainedConcrete Incorporating Large Volume of Fly Ash. Cement and Concrete Research. 30 (11): $1785-1789$

[37] Mehta, P.K., (2001), "Reducing the Environmental Impact of Concrete", as Cited by A.K.H Kwan, P.L and Fung, W.W.S, (2011), Research Directions for High Performance Concrete, Department of Civil Engineering, The University of Hong Kong, Pokfulam, Hong Kong.

[38] Mehta, P.K and Monteiro, P.J.M, (2006). Concrete Microstructure, Properties and Materials. $3^{\text {rd }}$ Edition, McGraw Hill, New york pp:659.

[39] Muga, H., K. Betz, J. Walker, C. Pranger, A. Vidor, (2005). Development of Appropriate andSustainable Construction Materials. Sustainable Future Institute, Michigan Technological University, Michigan, USA.

[40] Park, j., Tae, S., Kim, T., (2012). Life Cycle Assessment of Concrete by Compressive Strength on Construction Site in Korea. Renewable. Sustainable Energy Rev., 16: pp. 29402946.

[41] Raghu, T.A and Chaitanya, B.K, (2007). Partial Cement Replacement Materials. LongmanGroup, UK Ltd.

[42] Sakr, K., (2006). Effects of Silica Fume and Rice Husk Ash on the Properties of Heavy Weight Concrete. Journal of Materials in Civil Engineering; 18(3): pp. 367-376.

[43] Sata, V., C. Jaturapitakkul, Kiattikomol,K, (2007). Influence of Pozzolan from various By-product Materials on Mechanical Properties of High - Strength Concrete Construction and Building Material. 21(7):pp. 1589-1598.

[44] Siddique, F., (2008). Waste Materials and By-products in Concrete. Springer press. In: givi,N.A., S.A Rashid, F.N.A Aziz and S.M.A. Mohd, 2010. Contribution of Rice Husk Ash to the Properties of Mortar and Concrete: A Review. Journal of American Sciences, 6(3): 157-165

[45] Smith, R.G. and Kamwanja G.A, (1986). The Use of Rice Husk for Making a Cementitious Material, Proceeding of Joint Symposium on the Use of Vegetable Plants and Their Fibers as Building Material, Baghdad. In: N.A Givi, S.A. Rashid F.N.A. Aziz, S.M.A Mohd, 2010. Contribution of Rice Husk Ash to the Properties of Mortar and Concrete: A Review. Journal of American Sciences 6(3): 157-165.

[46] Tashima, M.M., C.A.R. Silva, J.L. Akasaki, M.B. Barbosa, (2004). The Possibility of Adding the Rice Husk Ash (RHA) to the Concrete. In: proceedings of the International RILEM Conference on the Use of Recycled Materials in Building and Structure November 8-11, 2004, Barcelona, Spain, pp: 778 $-786$.

[47] Toutanji, H.,Delatte, N., Aggoun, S., Duval, R., Danson, A, (2004). Effect of Supplementary Cementitious Materials on the Compressive Strength and Durability of Short-term Cured Concrete. Cem. Concr. Res., 34: 311-319.

[48] Zhang, M.H., R. Lastra, V.M. Malhotra, (1996). Rice Husk Ash Paste and Concrete: Some Aspects of Hydration and the Microstructure of the Interfacial Zone Between the Aggregate and Paste. Cement and Concrete Research, 26(6): pp. $963-$ 977. 